\title{
Photooxygenation of $N$-(2-thiazolyl)sulfanilamide, 2-(4-thiazolyl)benzimidazole, and Thiacetazone
}

\author{
Shubha Jain, ${ }^{*}$ Meena Chourey, and Srinivasa Rao Jetti \\ School of Studies in Chemistry and Biochemistry, Vikram University, Ujjain, Madhya Pradesh-456010, India
}

RECEIVED JANUARY 29, 2010; REVISED JUNE 19, 2011; ACCEPTED OCTOBER 12, 2011

Abstract. In the present work, photolysis of $\mathrm{N}$-(2-thiozolyl)sulfanilamide, 2-(4-thiazolyl)benzimidazole and thiacetazone in presence of benzophenone as a sensitizer under $125 \mathrm{~W}$ UV Lamp has been reported. Structures of the products have been established by spectral and elemental analysis. (doi: $10.5562 /$ cca1677)

Keywords: photolysis, $N$-(2-thiazolyl)sulphanilamide, 2-(4-thiazolyl)benzimidazole, thiacetazone, benzophenone

\section{INTRODUCTION}

Photolysis of organic compounds has been a vast field of research since a long time, ${ }^{1-15}$ almost all types of compounds have been studied so far. However there are no reports in the literature on the photolysis of $\mathrm{N}$-(2-thiazolyl)sulfanilamide, 2-(4-thiazolyl)benzimidazole and thiacetazone. Therefore, in the present work we have studied the photolysis of these compounds as these are medicinally important compounds having pharmacological applications.

Sulfonamide is an organic sulfur compound containing $-\mathrm{SO}_{2} \mathrm{NH}_{2}$ moiety. Its molecular structure is similar to p-aminobenzoic acid (PABA) which is needed in bacteria as a substrate of the enzyme dihydropteroate synthetase for the synthesis of tetrahydrofolic acid (THF). Sulfonamides, derived from chiefly sulfanilamide, are capable of interfering with the metabolic processes in bacteria that require PABA. ${ }^{16}$ They act as antimicrobial agents by inhibiting bacterial growth and activity and called sulfa drugs. ${ }^{17}$ They are used in the prevention and treatment of bacterial infections, diabetes mellitus, ${ }^{18}$ edema, ${ }^{19}$ hypertension ${ }^{20}$ and gout. ${ }^{21}$

Benzimidazole is a dicyclic compound having imidazole ring fused to benzene. Benzimidazole structure is a part of the nucleotide portion of vitamin B12 and forms the nucleus in some drugs such as proton pump inhibitors and anthelmintic agents. ${ }^{22}$

Benzimidazol and its derivatives are used in vermicides or fungicides as they inhibit the action of certain microorganisms. Thiabendazole, thiazole substitute of benzimidazole is a broad-spectrum benzimidazole class anthelmintic with activity against roundworms, pinworms, hookworms, and other helminth species which attack domestic animals and humans. ${ }^{23}$ Thiabendazole and its salts are general purpose fungicides, bactericides and wood preservatives to control mould, blight, and other fungal diseases in fruits and vegetables. They are also used as preservative in paints, carpets, textiles and adhesives. ${ }^{24}$ Thiabendazole also finds its application as a chelating agent to treat metal poisoning.

Thiacetazone (TAC) is a low cost, antitubercular, bacteriostatic drug that has been widely used in combination with isoniazid in Africa and South America. ${ }^{25}$ Chemical analogues of TAC, SRI-224 and SRI-286, have been synthesized and tested against Mycobacterium avium and found to be more effective than TAC in vitro and in mice. ${ }^{26}$ It has recently been shown that TAC is a prodrug that is activated by the mycobacterial monooxygenase EthA, which is also the activator of two other anti-tuberculosis drugs, ethionamide (ETH) and isoxyl (ISO). ${ }^{27-29}$ However, the mechanism of action of TAC remains an enigma.

\section{EXPERIMENTAL}

The substrates used in the present work are the commercially available compounds of Sigma-Aldrich make and are $98 \%$ pure (as claimed by the manufacturer). The compounds give single spot on tlc and show sharp melting points.

\footnotetext{
* Author to whom correspondence should be addressed. (E-mail: drshubhajain@yahoo.co.in)
} 
<smiles></smiles>

Scheme 1. Photolysis of $N$-(2-thiazolyl)sulfanilamide.

Photolysis of $\mathrm{N}$-(2-thiazolyl)sulfanilamide, 2-(4-thiazolyl)benzimidazole and Thiacetazone Using UV Source

The substrate $(2 \mathrm{~g})$ was dissolved in $200 \mathrm{ml}$ dried and distilled methanol. Benzophenone was added as a sensitizer. The solution was irradiated by $125 \mathrm{~W}$ UV source in neutral, acidic and alkaline medium, respectively in photo reactor for appropriate time.

The progress of the reaction was monitored by TLC. After the completion of the reaction, the reaction mixture was concentrated. The product was separated by preparative TLC using benzene: methanol (8:2) solvent system. The product was washed, dried, and recrystallised from methanol. $N$-(2-thiazolyl)-sulfanilamide gave product 2 (Scheme 1) 2-(4-thia-zolyl)benzimidazole gave the products 4 and $\mathbf{5}$ (Scheme 2) and thiacetazone gave products 7 and $\mathbf{8}$ (Scheme 3). Other details of the products are given in Table 1 .

\section{RESULTS AND DISCUSSION}

\section{Photolysis of $N$-(2-thiazolyl)sulfanilamide}

$\mathrm{N}$-(2-thiazolyl)sulfanilamide (1) when irradiated by UV light in presence of benzophenone, it underwent photolysis giving the product $\mathbf{2}$ as shown in Scheme 1. The structure of the product has been confirmed with the help of spectral and elemental analysis data.

The IR(KBr) spectrum of 2 shows peaks at $\tilde{v} / \mathrm{cm}^{-1}=3358.3 \quad(\mathrm{NH} \quad$ stretching $), 1593.7 \quad(\mathrm{C}=\mathrm{N}$ stretching), 1084.6 (CN stretching), 828.1 (aromatic $\mathrm{CH}$ bending) etc. The ${ }^{1} \mathrm{H}$ NMR (DMSO- $d_{6}$ ) spectrum gives peaks at $\delta / \mathrm{ppm}=7.2-6.5$ (aromatic protons), $3.48(\mathrm{NH}$<smiles></smiles>

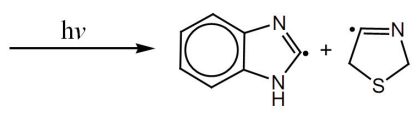

3<smiles></smiles>

Rearrangement<smiles></smiles>

Scheme 2. Photolysis of 2-(4-thiazolyl)benzimidazole.

and $\mathrm{NH}_{2}$ ). The ${ }^{13} \mathrm{C}$ NMR (DMSO- $d_{6}$ ) spectrum gives peaks at $\delta / \mathrm{ppm}=152.0(\mathrm{C}=\mathrm{N}$ carbon atom $), 141$ (C-S), $135(\mathrm{C}-\mathrm{N}), 124-130$ (aromatic carbon atoms).

\section{Photolysis of 2-(4-thiazolyl)benzimidazole}

$N$-(2-thiazolyl)benzimidazole (3) when irradiated by UV light in presence of benzophenone it underwent photolysis giving the products benzimidazole (4) and thiazole (5) as shown in Scheme 2. The structural elucidiation of the products has been done by co-TLC and mixed melting point with the authenic samples.

\section{Photolysis of Thiacetazone}

Thiactazone (6) when irradiated by UV light in presence of benzophenone underwent photolysis giving the products $N$-phenyl-acetamide (7) and thiourea (8) as shown

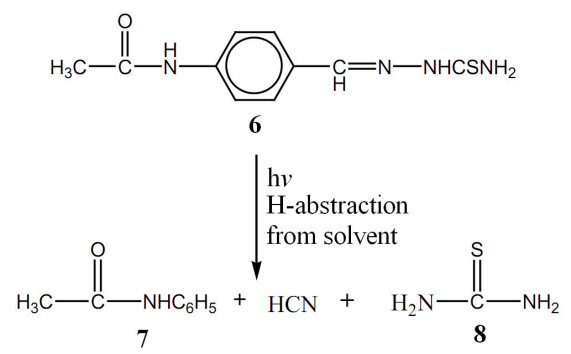

Scheme 3. Photolysis of thiacetazone.

Table 1. The products obtained by the UV photolysis of $N$-(2-thiazolyl)sulfanilamide, 2-(4-thiazolyl)benzimidazole and thiacetazone

\begin{tabular}{|c|c|c|c|c|c|}
\hline Substrate & Product & Reaction time / h & Yield / g & Melting point $/{ }^{\circ} \mathrm{C}$ & Elemental Analysis $(w / \%)$ \\
\hline \multirow{2}{*}{$\begin{array}{c}N \text {-(2-thiazolyl)sulfanilamide } \\
\text { (1) }\end{array}$} & \multirow{2}{*}{2} & \multirow{2}{*}{50} & \multirow{2}{*}{1.45} & \multirow{2}{*}{156} & $\begin{array}{c}\text { Found: } \\
\text { C 56.45, H 4.67, S 16.72, } \\
\text { N 21.91 }\end{array}$ \\
\hline & & & & & $\begin{array}{c}\text { Calculated for } \mathrm{C}_{9} \mathrm{H}_{9} \mathrm{~N}_{3} \mathrm{~S} \text { : } \\
\text { C 56.52, H 4.74, S 16.77, } \\
\text { N } 21.97\end{array}$ \\
\hline \multirow{2}{*}{$\begin{array}{c}\text { 2-(4-thiazolyl)benzimidazole } \\
\text { (3) }\end{array}$} & 4 & 41 & 0.8 & 170 & \\
\hline & 5 & 41 & 0.7 & 223 & \\
\hline \multirow{2}{*}{$\begin{array}{l}\text { Thiacetazone } \\
\text { (6) }\end{array}$} & 7 & 51 & 0.65 & 165 & \\
\hline & 8 & 51 & 0.72 & 177 & \\
\hline
\end{tabular}


ucts $N$-phenyl-acetamide (7) and thiourea (8) as shown in Scheme 3. The structural elucidiation of the products has been done by co-TLC and mixed melting point with the authenic samples.

\section{CONCLUSION}

All the three compounds are photochemically active and undergo photodegradation on prolonged exposure to UV light.

Acknowledgements. The authors are thankful to the authorities of R.S.I.C., C.D.R.I Lucknow for providing spectral and elemental analysis data.

\section{REFERENCES}

1. C.F. Chignelli, B. Kalyanaraman, and R.H. Sik, J. Photochem. Photobiol. 34 (2) (1981) 147-156.

2. G. Crank and A. Mursyidi, Aust. J. Chem. 34 (4) (1982) 775-784.

3. T. Ahamad and J. Ahamad, Pol. J. Pharmacol Pharm. 35 (1) (1983) 69-75.

4. Amitbodh Upadhayaya and Shubha Jain, J. Ind. Council Chem. 14 (2) (1997) 20.

5. T. Nakayama, T. Shimizu, Y.Torii, S. Miki, and K. Hamanoue, J. Photochem. Photobiol. A 111 (1-3) (1997) 35-39.

6. A. Posadaz, E. Sanchez, M. J. Gutierrez, M. Caderon, S.Bertolotti, M. A. Biasothi, and N. A. Garcis, Dyes Pigm. 43 (3) (2000) 219-228.

7. S. S. Chawada and S. Jain, Ind. J. Chem. Sec. B. 41B (2002) 865.

8. C. Arh-Hwang, K. Wei-Bao, and Chia-Wen, J. Chin. Chem. Soc. 50 (2003) 123-127.

9. S. Jain, A. Upadhyaya, and B.Kheradia, Int. J. Chem.Sci. 1 (2) (2003) 107-110

10. J. Delgado, A. Espinós, M. Consuelo Jiménez, and M. A. Miranda,
Arkivoc (8) (2007) 224-230.

11. S. Jain, R. B. Pandey, and M. Chourey, Indian J. Chem. 43B (2004) 2245-2248.

12. T. Kametani, H. Sugi, S. Shibuya, and K. Fukumoto, Tetrahedron 27 (1971) 5375-5379.

13. L. T. Quyen, U. Himmelreich, and K. Schreiber, European. J. Chem. 7 (1997) 1589- 1592.

14. M. W. Lam and S. A. Mabury, Aquat. Sci. 67 (2) (2005) 177-188.

15. S. Jain and S. Singh Chawada, Ind. J. Heterocyclic Chem. 11 (2002) 247.

16. J. E. Anderson, S. Moore, F. Tarczynski, and D. Walker, Spectrochim. Acta Part A: Molecular and Biomolecular Spectroscopy 57 (9) (2001) 1793-1808.

17. D. Hughes, M. Hursthouse, B. Lancaster, S. Tavener, T.Threlfall, and P. Turner, Acta Crystallogr. C55 (1999) 1831.

18. Auguste Louhatieres, Annals of the New York Academy of Sciences 67 (1956) 187-206.

19. E. S. Hemmens and G. M. Dack, J. Infect. Dis. 64 (1) (1939).

20. M. Patlak, FASEB J. 18 (2004) 421.

21. J. Frank Doughty and M. D. Tracy, Clinical notes - case reports. (1941) 203.

22. M. Rangel, E. Pereira, and Baltazar de Castra, J. Organomet. Chem. 632 (1-2) (2001) 85-93.

23. T. Chandra and K. L. Brown, Tetrahedron Lett. 46 (2005) 86178619 .

24. V. O. Khokhlachev and A. I. Ponyaev, Russ. J. Gen. Chem. 77 (2007) 1406- 1409.

25. P. T. Davidson and H. Q. Le, Drug Treatment of Tuberculosis 43 (1992) 651-673.

26. L. E. Bermudez, R. Reynolds, P. Kolonoski, P. Aralar, and C. B. Inderlied, Antimicrob Agents Chemother. 47 (2003) 2685-2687.

27. L. G. Dover, A. Alahari, P. Gratraud, J. M. Gomes, and V Bhowruth, Antimicrob Agents Chemother. 51 (2007) 1055-1063.

28. L. Qian, P. R. Ortiz de Montellano, Chem. Res. Toxicol. 19 (2006) 443-449.

29. A. E. DeBarber, K. Mdluli, M. Bosman, L. G. Bekker, and C. E. Barry, Proc Nat. Acad. Sci. 97 (2000) 9677-9682. 